\title{
REDUCTION OF LOCAL SCOUR AROUND OBLONG BRIDGE PIERS USING SLOTS
}

\author{
Prof. Gamal Abozeid ${ }^{1}$, Dr. Moustafa S. Darweesh ${ }^{2}$ and Eng. Hend H. Saleh ${ }^{3}$. \\ 1Professors of hydraulics \& water resources, Civil Eng. Dept., Assiut Univ., 71516 \\ 2 Assistant Professor, Civil Engineering Dept., Assiut University, 71516 Assiut. \\ ${ }^{3}$ M. Sc. student, Eng. At Ministry of water resources and public work, Egypt. \\ First author e-mail: gabozeid@yahoo.com
}

\begin{abstract}
This article presents an intensive experimental work for investigating the effect of rectangular slots and pier groups with various arrangements on the scour around bridge piers. Slots near the bed through an oblong pier with different arrangements and replacing the solid pier by two pier groups were provided to show their influence on the variation of scour dimensions under clear-water conditions. Water flow rate is varied four times $(18,15,12.5$ and $10.5 \mathrm{lit} / \mathrm{s})$, while the water depth covers a range of Froude number from 0.089 to 0.25 which is suitable for Egyptian canals. The scour hole dimensions and water depths are measured using calibrated point gages. The factors impacting the scour problem are normalized with the help of dimensional analysis theory. The experimental results show the efficient method that decreases the scour hole dimensions is the pier groups (pier type 7), where the scour depth, width and length reduced by 93,73 , and $79 \%$ respectively. Slots within the oblong piers decrease the scour dimensions (depth, width and length) by 92, 53, and $69 \%$, respectively. These findings can easily safeguard the bridge piers and dramatically reduce the maintenance efforts and costs as well as improve the hydraulic performance of the water structures.
\end{abstract}

Keywords: Oblong Pier, Group Piles, Slots, Scour Depth

\section{INTRODUCTION}

Scour phenomena can be defined as the removal of soil from the stream bed and its banks by the erosive action of the stream flow. Many researchers have studied this phenomenon. Numerically and experimentally, Abozeid et al., 2006[2] investigated the flow characteristics and their relation to scour around single and double piles supporting bridges. They found that in addition to the flow parameters the scour length depend upon the pile shape and the distance between the two piles. The major damage to the bridges occurs during the periods of floods or flash floods. There are various reasons for such damages; the prime reason being the widely known local scour of streambeds at the bridge piers and abutments (Siddiqui and Elsebaie
[21]). Local scour at bridge piers may be defined as 'a local lowering of the bed elevation around a pier'. This lowering is mainly caused by the horseshoe vortex combined with the down flow in front of the pier (Moncada-M et al. [18]). According to Melville [15], the downward flow acts as a vertical jet in eroding the bed. Also, he [15] reported that the downward flow is the initial cause of the scour and the horseshoe vortex is a consequence of the scour and not the cause of it where it is initially small and weak. There were several methods which would reduce scour at bridge piers or inhibit its development.

One of the methods to reduce the power of the horseshoe vortex is using slots. It creates a conduit for passing the flow through the pier 
of the bridge (Khodabakhshi et al. [13]). A slot through a pier reduces the scour by decreasing the strength of the horseshoe vortex due to the reduction of effective diameter of the pier. Furthermore, the passage of water through the slot reduces the intensity of adverse pressure gradient upstream of the pier. The slot helps to pass most of the flow through it and only the balance is left to cause much reducing scour damage. The geometry of the slot is simple, although its field applications are fraught with other complications like structural weakening of the pier and the choking of slot due to floating debris, Setia and Bhatia [20]. Chiew [7] studied the protection of bridge piers against scouring by using slots and collars. The tests result demonstrated that using only one slot can lead to a $20 \%$ reduction in scouring especially if the slot is close to the water surface or bed. Kumar et al. [14] showed that the slot was effective in decreasing scouring but the slotted pier would not be effective if the flow approaching the pier shows a great deviation. Heydarnejad et al. [12] investigated the effect of slots on the scouring around piers in different positions of 180degrees bends and found that the maximum reduction scour depth is $24 \%$. Grimaldi et al. [11] examined the behavior of slots on local scour around the piers and they obtained a depression in the scour depth by approximately 30\%. Christensen [9] stated that slots could lead to reduce the scour around aerofoil shaped piers compared with circular piers. El-Razek et al. [10] studied experimentally the scour around bridge piers provided with internal openings. They proved that, for circular piers, the best alignment for the openings is one in the front and connected to two other openings in the same level one on each side of the pier. This arrangement reduced the maximum scour depth by $30.4 \%$. Also, the openings decreased the volume of the scoured material by average value of $54 \%$. The experimental results by Khodabakhshi et al. [13] elucidated that when the height of a slot is below the stream bed, scour depth and scour volume will be reduced about $20.34 \%$ to $39.73 \%$ and by $46.84 \%$ to $75.74 \%$, respectively.

There are many approaches available for scour protection, but most of them are economically expensive and construction cost is also more. Vittal et al. [23] studied experimentally replacing the solid pier by a group of three smaller piers, solid pier diameter equals to the circumscribing circle diameter of the pier group. They observed that a pier group is much more effective than on a solid pier, as the scour reduction reached $40 \%$. The above review of literature shows that although a substantial work has been carried out on local scour around bridge piers, the local scour around an oblong bridge pier is not studied widely and more investigations are needed to understand the phenomenon of local scour in a better manner. However, the study on scour under steady condition on oblong pier with slots is limited. So, the prime aim of the present research is to examine the influence of rectangular slots with different aspects through an oblong pier, under clearwater conditions. Also, solid pier are replaced the by two pier groups (of diameter equals to the circumscribing circle diameter of the solid pier) which match a multi-slot, on the scour phenomenon, and hence specify the optimum model.

\section{DIMENSIONAL ANALYSIS}

For a specific discharge and water depth, scour depth around a bridge pier develops with time. In general, scour depth is related to fluid flow, sediment properties, pier geometry, and time (Melville and Coleman [17], Choi and By ungwoong [8]). The depth of scour $d_{s}$ can be expressed as follows:

$\mathrm{d}_{\mathrm{s}}=f\left(\mathrm{~B}, \mathrm{~b}, \mathrm{~b}_{\mathrm{s}}, \mathrm{h}_{\mathrm{s}}, \mathrm{L}, \mathrm{L}_{\mathrm{s}}, \mathrm{l}_{\mathrm{s}}, \mathrm{t}, \mathrm{t}_{\mathrm{s}}, \mathrm{w}_{\mathrm{s}}, \mathrm{d}_{50}, \mathrm{~g}, \mathrm{u}, \mathrm{u}_{\mathrm{c}}\right.$, $\left.\mathrm{Q}, \mathrm{y}, \alpha, \mu, \rho_{w}\right)$

in which: $\mathrm{u}=$ mean velocity of flow, $\mathrm{u}_{\mathrm{c}}=$ critical flow velocity for the initiation of 
sediment motion, $\mathrm{Q}=$ the discharge, $\mathrm{y}=$ the flow depth, $\alpha=$ angle of attack of the approach flow with the models' axis, $\mu=$ dynamic viscosity, $\rho=$ density of water, $\mathrm{B}=$ width of main channel, $b=$ pier width, $L=$ pier length, $b_{s}=$ slot width, $L_{s}=$ slot length, $h_{s}=$ slot height, $\mathrm{t}=$ time, $\mathrm{t}_{\mathrm{s}}=$ time to equilibrium , $1_{\mathrm{s}}=$ max length of scour hole, $\mathrm{w}_{\mathrm{s}}=$ max width of scour hole, $\mathrm{d}_{50}=$ median sediment grain diameter, $\mathrm{g}=$ gravitational acceleration. Applying the method of dimensional analysis, Eqn. (1) can be written in non-dimensional form as:

$\frac{d_{s}}{y}$ or $\frac{w_{s}}{b}$ or $\frac{l_{s}}{b}=f_{2}\left(F_{r}, R_{e}, \frac{u}{u_{c}}, \frac{Q}{b^{2} u}, \frac{y}{b}, \frac{B}{b}, \frac{b_{s}}{b}\right.$, $\left.\frac{h_{s}}{b}, \frac{L}{b}, \frac{L_{s}}{b}, \frac{t u}{b}, \frac{t_{s} u}{b}, \frac{d_{50}}{b}, \alpha\right)$

in which: $F_{r}=$ Froude number of the incoming flow $u / \sqrt{g y}$, and $R_{e}=$ Reynolds' number $=$ $\rho b u / \mu$ (its effect in open channels may be neglected (Ali, 1978[3] and Chatterjee and Ghosh,1980[6]). After applying dimensional analysis properties and by eliminating the variables that are not very influential to scour e.g. Re, $\alpha$ (A model bridge arrangement has been made in such a way that the pier axis is perpendicular to the water flow direction) and those with constant values in this study such as: $\mathrm{d}_{50}, \mathrm{~B}, \mathrm{~L}, \mathrm{~b}_{\mathrm{s}}, \mathrm{L}_{\mathrm{s}}, \mathrm{h}_{\mathrm{s}}, \mathrm{t}$ and $\mathrm{t}_{\mathrm{s}}$ (considered the equilibrium time of all the experiments equals to 3 hours), Eqn. (2) may be simplified to:

$$
\frac{d_{s}}{y} \text { or } \frac{w_{s}}{b} \text { or } \frac{l_{s}}{b}=f_{3}\left(F_{r}, \frac{u}{u_{c}}, \frac{Q}{b^{2} u}\right)
$$

\section{EXPERIMENTAL SETUP}

The experiments were conducted in a tilting flume located in the gallery of hydraulics laboratory of Civil Engineering Department, Assiut University in Egypt. A rectangular flume $(0.5 \mathrm{~m}$ height, $0.3 \mathrm{~m}$ wide and $20 \mathrm{~m}$ long of smooth painted bed). The discharge was made re-circulatory by using a centrifugal pump. The working section of $17.5 \mathrm{~m}$ in length is made transparent from plexiglass fixed to steel frame. The inlet part of the flume consists of a forebay with dimension $(0.5 \times 0.75 \mathrm{~m})$. The depth of water is adjusted by a revolving tailgate which is installed at the downstream end of the flume. The recirculating system consists of an electrically driven centrifugal pump, and a $100 \mathrm{~mm}$ diameter pipeline to accommodate different flow rates. To control the water flow rate, a gate valve is installed on the pipeline at the delivery side of the pump. An orifice meter connecting to a manometer scale for measuring the discharge is located at the delivery pipe behind the valve. (see Photo (1)) 


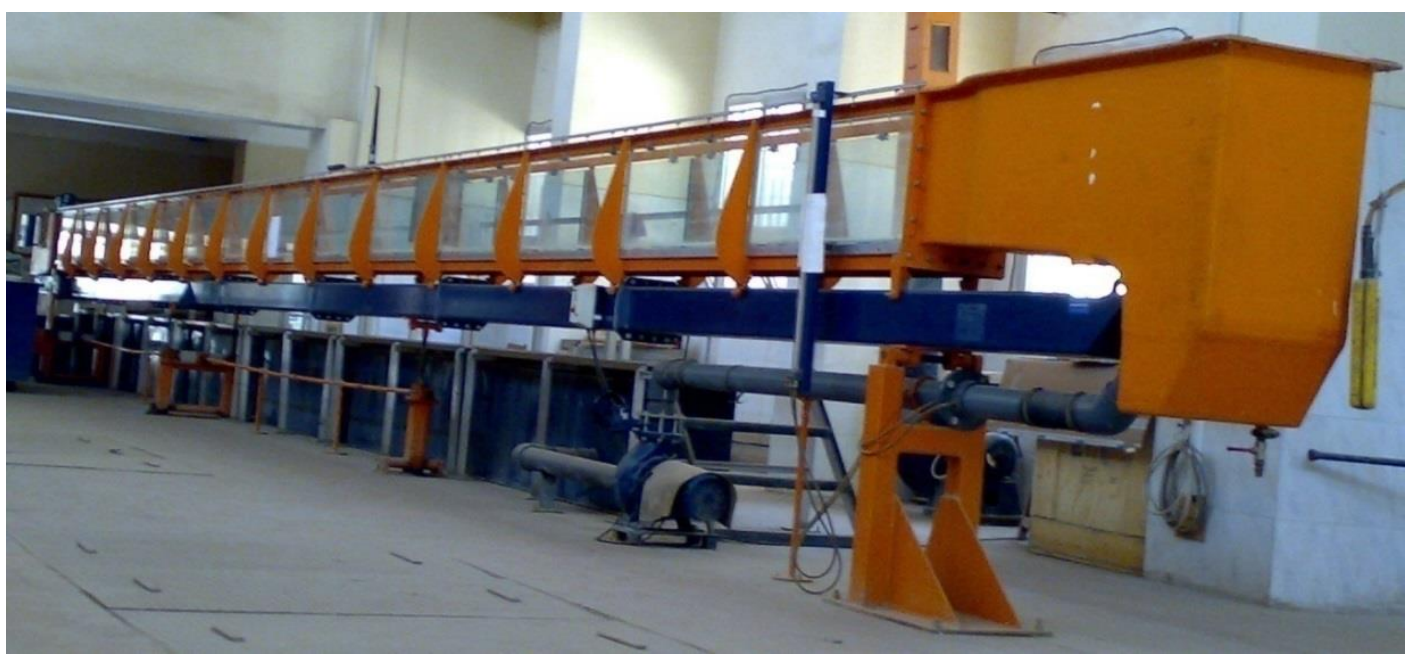

Photo (1): General view of the re-circulating flume.

\section{DESCRIPTION OF THE} EXPERIMENTS

Five wooden oblong piers with width $3.0 \mathrm{~cm}$, and $15 \mathrm{~cm}$ length without and with rectangular slots differ in shape were installed in the channel centerline and two other models consist of six glass piers with $0.75 \mathrm{~cm}$ diameter with two arrangements, were used as shown in Fig. (1). Sand basin with longitudinal length of $2.00 \mathrm{~m}$ and height of 20 $\mathrm{cm}$ are furnished by clean regular sand particles having mean size, $\mathrm{d}_{50}=0.71 \mathrm{~mm}$. The flow rate was changed four times $(18,15$, 12.5 and $10.5 \mathrm{~L} / \mathrm{s}$ ). The tested model is fixed in the sand basin which located at $5.5 \mathrm{~m}$ away from the entrance of the flume. False floor was constructed along the remaining length of the flume with $0.20 \mathrm{~m}$ above the bottom.

According to Breusers and Raudkivi [4], the flume width should be at least as eight times as the size of the pier width for clear water scouring conditions, so the effect of the channel walls and sediments size on scouring depth can be eschewed. For minimize the effect of flow shallowness on scour, for fine sediments, ratio of flow depth to pier diameter (y/b) must be greater than 2, thus the flow depth was elected equals 18, 20, 22 and 25 $\mathrm{cm}$. Clear water scouring occurs when the ratio of average flow velocity, (u) to threshold velocity for bed sediments $\left(u_{c}\right)$ is less than or equal to unity (Melville and Chiew [16]). In contrast, moving bed scouring occurs when $\left(\mathrm{u} / \mathrm{u}_{\mathrm{c}}>1.0\right)$.

A number of different approaches have been proposed to calculate the critical velocity. However, in this study, Chang and Davis's [7] method was employed. The curves and diagrams suggested by Neil [19] are transformed into a series of relationships to calculate the critical velocity based on the flow depth and the average diameter of soil particles. These relationships are:

For:

$\mathrm{d}_{50}>0.03 \mathrm{~m} ; \mathrm{u}_{\mathrm{c}}=\mathrm{k}_{\mathrm{u}}(11.5) \mathrm{y}^{1 / 6} \mathrm{~d}_{50}^{1 / 3}$

For:

$0.03 \mathrm{~m}>\mathrm{d}_{50}>0.0003 \mathrm{~m}$;

$\mathrm{u}_{\mathrm{c}}=\mathrm{k}_{\mathrm{u} 1}(11.5) \mathrm{y} \mathrm{d}_{50}^{0.35}$

Where:

$\mathrm{x}$ can be calculated as follows: $x=k_{u 2 d_{50}^{02}}^{0.123}(6)$

For:

$\mathrm{d}_{50}<0.0003 \mathrm{~m} ; \mathrm{u}_{\mathrm{c}}=\mathrm{k}_{\mathrm{u}} \sqrt{\mathrm{y}}$

and

$\mathrm{K}_{\mathrm{u}}=0.55217, \mathrm{k}_{\mathrm{u} 1}=0.3048^{(0.65-\mathrm{x})}$ and $\mathrm{k}_{\mathrm{u} 2}=$ 0.788

The experiments were started by carefully filling the flume with water to the required flow depth. This was done with great care so 
as not to cause too much disturbance to the flow. Point gauges of $0.1 \mathrm{~mm}$ accuracy were used for measuring water depth in the longitudinal direction and the profile of the scour hole. For every experiment, the discharge was kept the same and the water was allowed to flow for duration of 3 hours. After each defined interval, the elevation of the sand bed was gauged with the same moving gauge. Scour depth measurements were recorded along three directions which were: longitudinal $(x)$, transverse $(y)$ and vertical (z) directions. A total of 16 experiments were done for each model for different flow conditions as listed in Table (1). The experiments were conducted to investigate the effect of rectangular slots and pier group on the scour-hole dimensions and to observe the variation of the scour-hole under the condition of clear-water scour. Table (2) shows the range of variables used in the experiments. Sieve analysis was used to determine grain sizes distribution and to find the grain size $d_{50}$ of the soil used in this study.

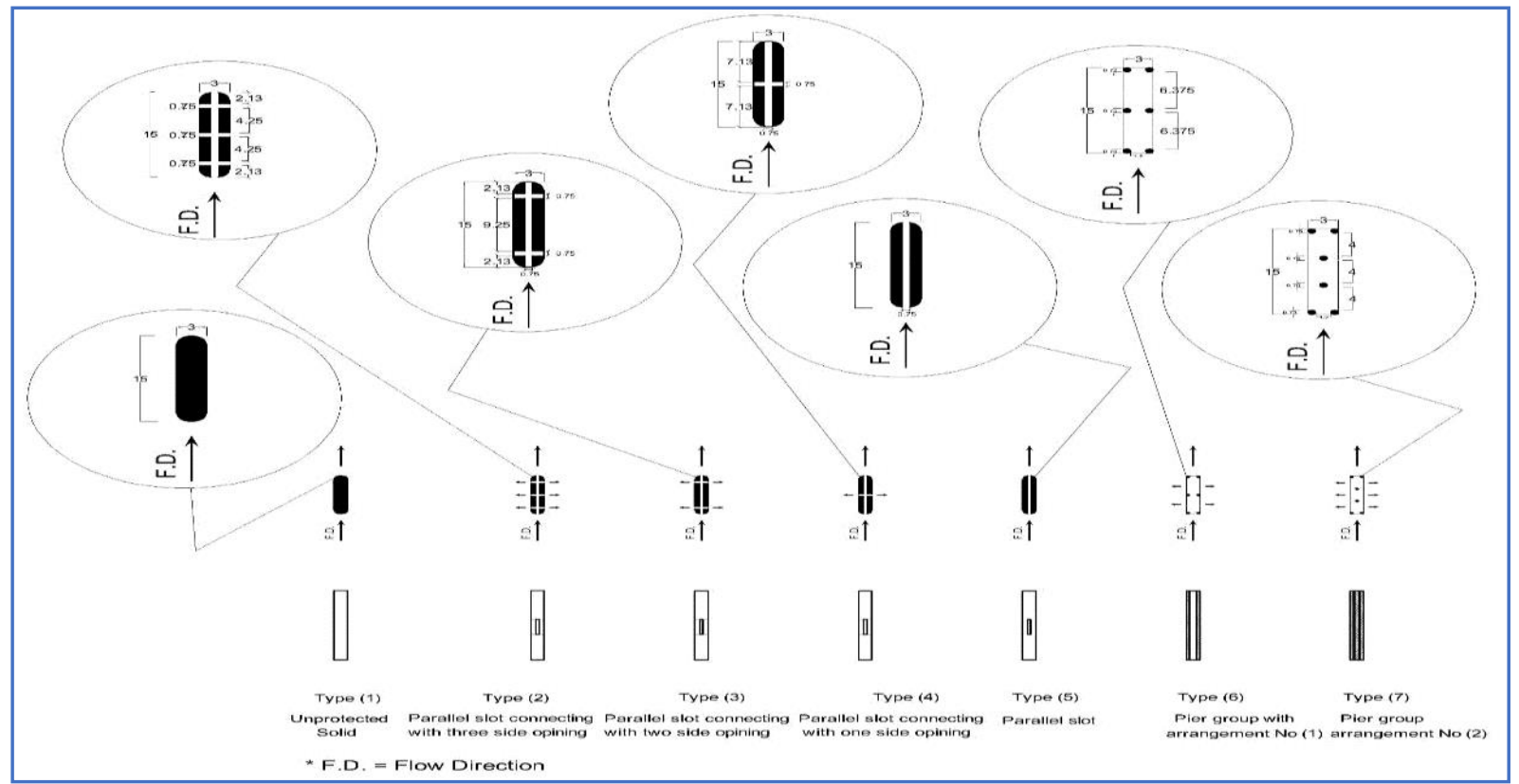

Fig. 1: Experimental models of piers investigated in the study.

The equilibrium time experiment was conducted under the most critical conditions (discharge is $18 \mathrm{l} / \mathrm{s}$, flow depth equals $18 \mathrm{~cm}$ for pier without slots). The graph showed that the increase scouring depth was insignificant after three hours (see Figure 2). Consequently, in all of the remaining tests, the equilibrium time was considered as three hours. Table (1) illustrates the results of calculating the critical velocity and $\left(\mathrm{u} / \mathrm{u}_{\mathrm{c}}\right)$ ratios with the application of Eq. 5, clear water scouring occurred because $\left(0.36<\mathrm{u} / \mathrm{u}_{\mathrm{c}}<0.99\right)$.

Table1. Critical velocity and $\left(\mathrm{u} / \mathrm{u}_{\mathrm{c}}\right)$ ratios calculated by using Eqn. (5) for all models.

\begin{tabular}{|c|c|c|c|c|c|c|c|c|c|}
\hline Run No. & $\mathbf{Q}(\mathbf{l} / \mathbf{s})$ & $\mathbf{y}(\mathbf{c m})$ & $\mathbf{u}(\mathbf{m} / \mathbf{s})$ & $\mathbf{d}_{\mathbf{5 0}}(\mathbf{m m})$ & $\mathbf{k}_{\mathrm{u}}$ & $\mathbf{x}$ & $\mathbf{K}_{\mathrm{u} 1}$ & $\mathbf{u}_{\mathrm{c}}(\mathbf{m} / \mathbf{s})$ & $\mathbf{u}_{\mathbf{u}}$ \\
\hline 1 & 18 & 18 & 0.333 & 0.710 & 0.788 & 0.413 & 0.755 & 0.338 & 0.987 \\
2 & 18 & 20 & 0.300 & 0.710 & 0.788 & 0.413 & 0.755 & 0.353 & 0.850 \\
3 & 18 & 22 & 0.273 & 0.710 & 0.788 & 0.413 & 0.755 & 0.367 & 0.743 \\
4 & 18 & 25 & 0.240 & 0.710 & 0.788 & 0.413 & 0.755 & 0.387 & 0.620 \\
\hline
\end{tabular}




\begin{tabular}{|c|c|c|c|c|c|c|c|c|c|}
\hline 5 & 15 & 18 & 0.278 & 0.710 & 0.788 & 0.413 & 0.755 & 0.338 & 0.822 \\
6 & 15 & 20 & 0.250 & 0.710 & 0.788 & 0.413 & 0.755 & 0.353 & 0.708 \\
7 & 15 & 22 & 0.227 & 0.710 & 0.788 & 0.413 & 0.755 & 0.367 & 0.619 \\
8 & 15 & 25 & 0.200 & 0.710 & 0.788 & 0.413 & 0.755 & 0.387 & 0.517 \\
9 & 12.5 & 18 & 0.231 & 0.710 & 0.788 & 0.413 & 0.755 & 0.338 & 0.685 \\
10 & 12.5 & 20 & 0.208 & 0.710 & 0.788 & 0.413 & 0.755 & 0.353 & 0.590 \\
11 & 12.5 & 22 & 0.189 & 0.710 & 0.788 & 0.413 & 0.755 & 0.367 & 0.516 \\
12 & 12.5 & 25 & 0.167 & 0.710 & 0.788 & 0.413 & 0.755 & 0.387 & 0.431 \\
13 & 10.5 & 18 & 0.194 & 0.710 & 0.788 & 0.413 & 0.755 & 0.338 & 0.576 \\
14 & 10.5 & 20 & 0.175 & 0.710 & 0.788 & 0.413 & 0.755 & 0.353 & 0.496 \\
15 & 10.5 & 22 & 0.159 & 0.710 & 0.788 & 0.413 & 0.755 & 0.367 & 0.433 \\
16 & 10.5 & 25 & 0.140 & 0.710 & 0.788 & 0.413 & 0.755 & 0.387 & 0.362 \\
\hline
\end{tabular}

Table2. Range of variables for laboratory experiments:

\begin{tabular}{|c|c|c|c|c|c|}
\hline \multirow{2}{*}{ Parameter } & \multirow{2}{*}{ Symbol } & \multirow{2}{*}{ Value } & \multicolumn{2}{|c|}{ Range } & \multirow{2}{*}{ Units } \\
\cline { 4 - 5 } & Pier type & $1,2,3,4,5,6,7$ & 1 & 7 & - \\
\hline Pisch diameter & $Q$ & $10.5,12.5,15,18$ & 10.5 & 18 & $\mathrm{l}$ - \\
\hline Froude number & $F_{r}$ & Varied & 0.089 & 0.25 & - \\
\hline Mean water depth & $y$ & $18,20,22,25$ & 18 & 25 & $\mathrm{~cm}$ \\
\hline Sediment size & $d_{50}$ & 0.71 & - & - & $\mathrm{mm}$ \\
\hline
\end{tabular}

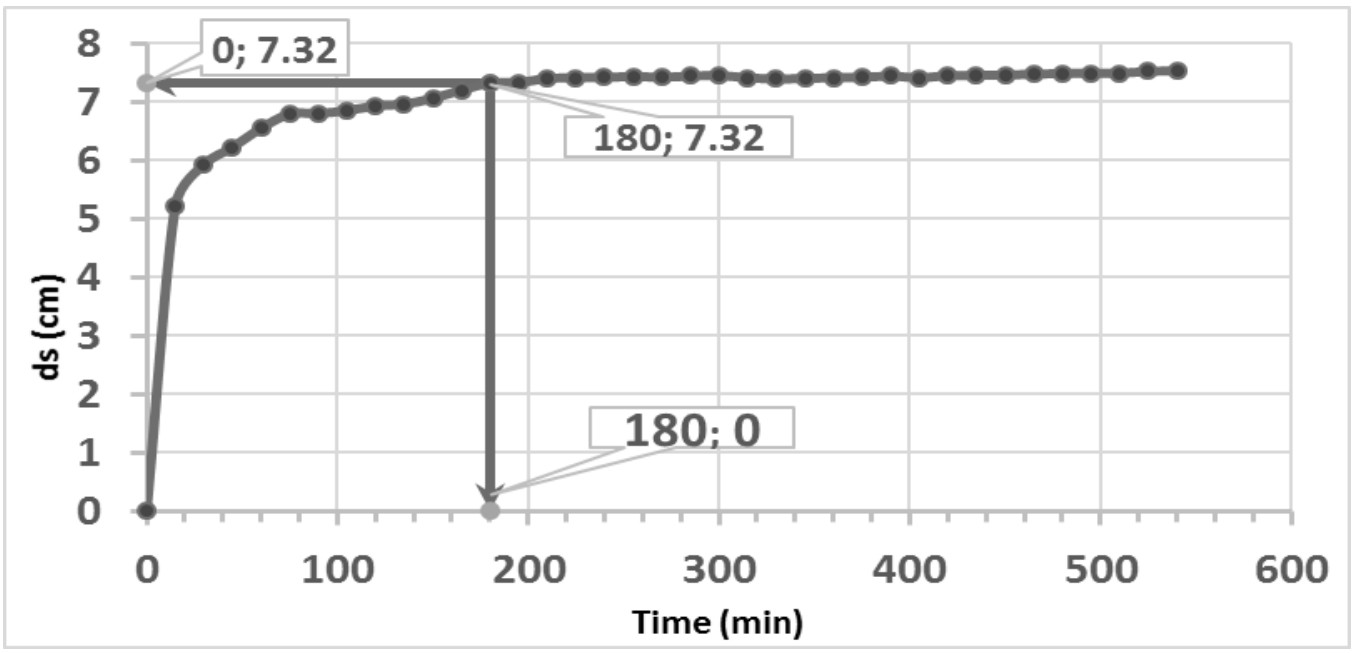

Fig.2. Equilibrium time at $\mathrm{Q}=18.0 \mathrm{l} / \mathrm{s}$ and $\mathrm{y}=18.0 \mathrm{~cm}$ in case oblong pier without slots.

\section{RESULTS AND DISCUSSION}

About 112 experimental runs were carried out. The profile of scour hole in plan and cross section through canal centerline were plotted to find the maximum scour depth, width, length and the volume of scoured material.

The plots of bed contours for some of the simulated results on pier types (1), (3), and (7) are shown respectively as in Figs. $(3,4,5)$. The plots are for a discharge of 18 lit/sec. and approach flow depth of $20 \mathrm{~cm}$. During the experiments, the scour hole was first observed in a region $\pm 45^{\circ}$ with the pier axis at the upstream direction and deepened rapidly. The drawings show an increase of the scour hole area around the piers with deeper depth at the upstream side and shallower one at the 
downstream, with its maximum value near the pier's nose. The minimum value of scour depth occurred in front of all piers. These results agree with those from previous researches of Tseng et al. [22] and Zarrati et al. [24]. Also, the maximum scour hole depth for pier types (3) and type (7) are lower than those for pier type (1) by $92 \%$ and $93 \%$, respectively. Moreover, for model type (7) the extension of scour hole increases downstream with shallower depth than for model type (3). So, the internal openings have an appreciable effect in reducing the scour hole dimensions. This may due to damping vortex formation in front of the pier. Therefore, the pressure difference around the pier drives the flow through the front openings and that along the pier's sides. By replacing solid pier by two pier groups (of diameter equal to the circumscribing circle diameter of the solid pier), which is akin to a multi-slot, the results show that the devices (types 6 and 7) are more effective than the internal openings in reducing the scour phenomenon.

Figures (6 and 7) show a longitudinal section through the scour hole (just near the pier). The figures compare between all seven models for the same conditions (discharge, flow depth, Froude number) for discharge $18 \mathrm{lit} / \mathrm{s}$, water depth $=20 \mathrm{~cm}$, and Fr $=0.21$, while the pier shapes were varied. It was seen that the scour hole is deeper in the upstream side of the piers in comparison with its downstream side. This may due to the vertical components of velocity and the horseshoe vortex, which are stronger upstream and around the piers. Also, the upstream inclination surface of scour hole profile is steeper than that downstream side, and the maximum scour hole occurs at pier type (1), while the used devices reduce the scour depth dramatically. As mentioned before, the minimum scour hole depth occurred at pier type

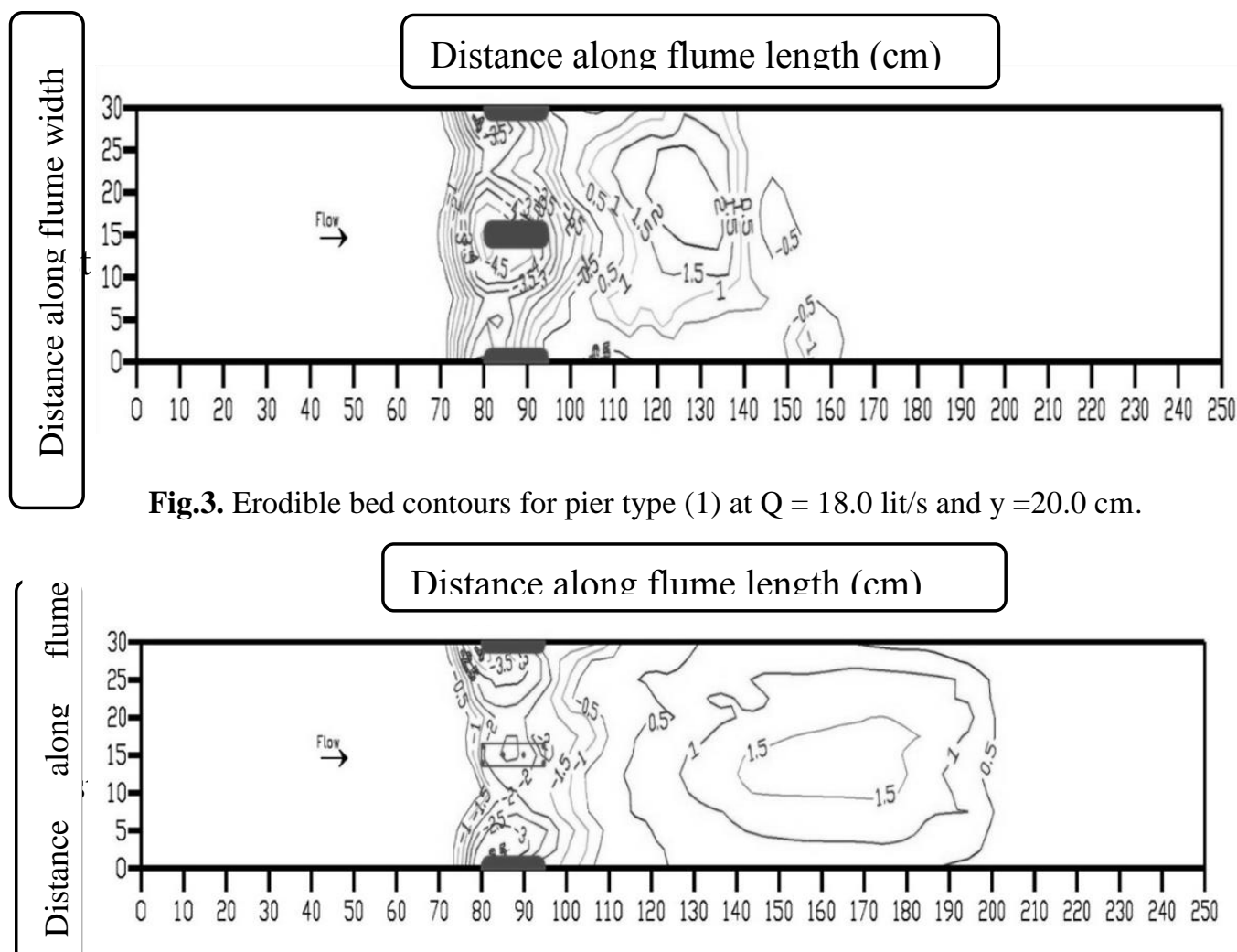

Fig.4: Erodible bed contours for pier type (3) at $Q=18.0$ lit/s and y $=20.0 \mathrm{~cm}$. 


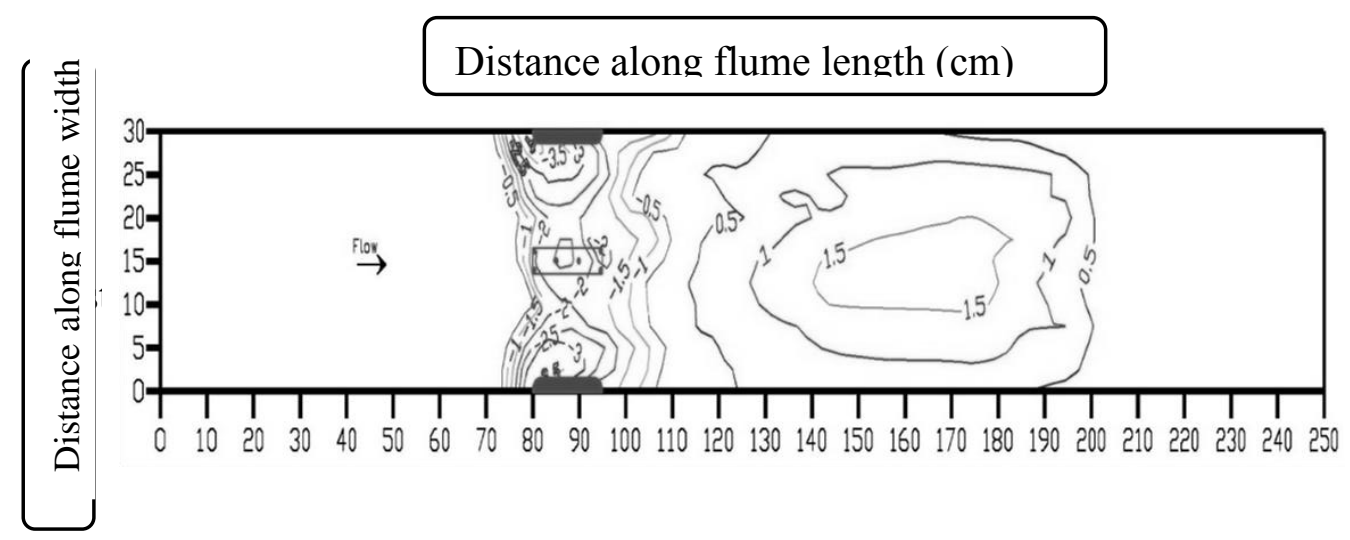

Fig.5. Erodible bed contours for pier type (7) at $Q=18.0$ lit/s and $y=20.0 \mathrm{~cm}$.

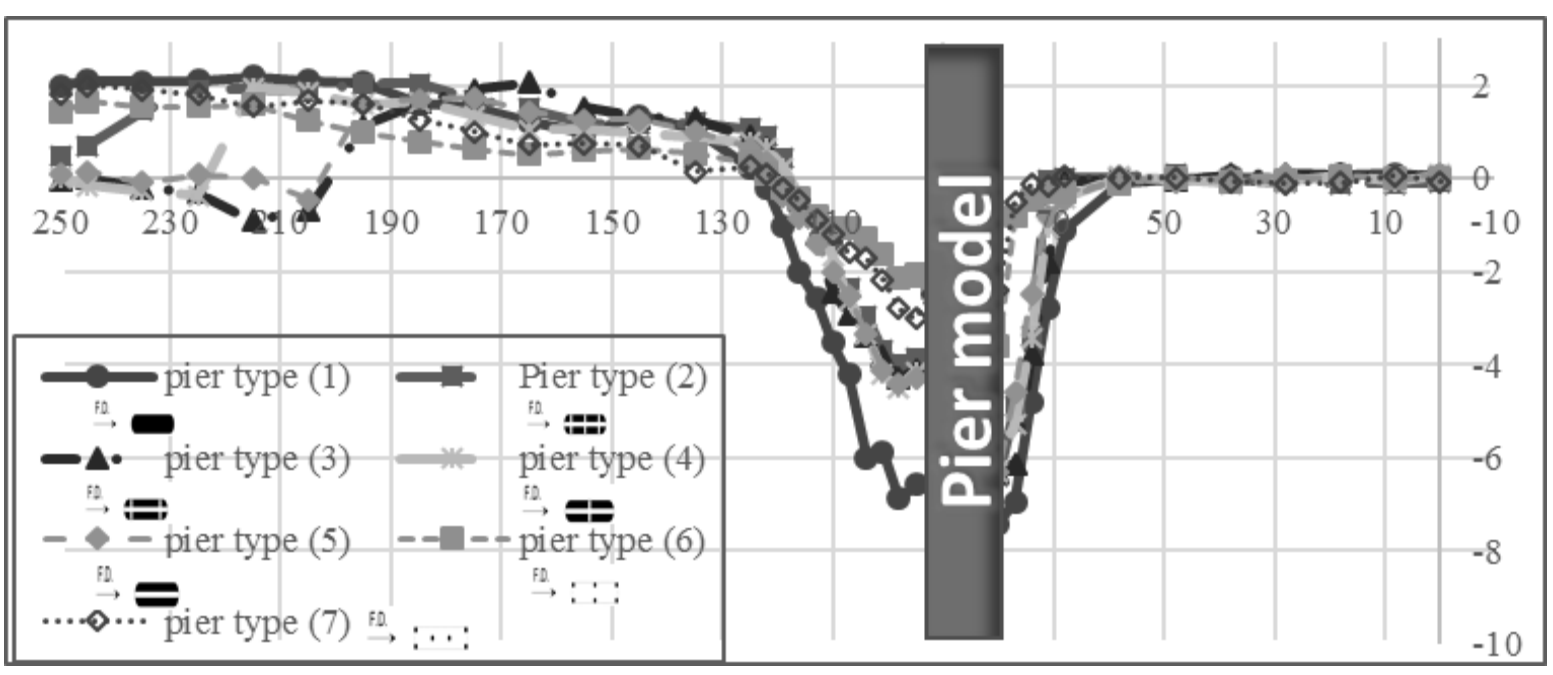

Fig.6. Longitudinal scour hole profile for studied pier types at $Q=18$ lit $/ \mathrm{s}, \mathrm{y}=18.0 \mathrm{~cm}$ and $\mathrm{F}_{\mathrm{r}}=0.25$.

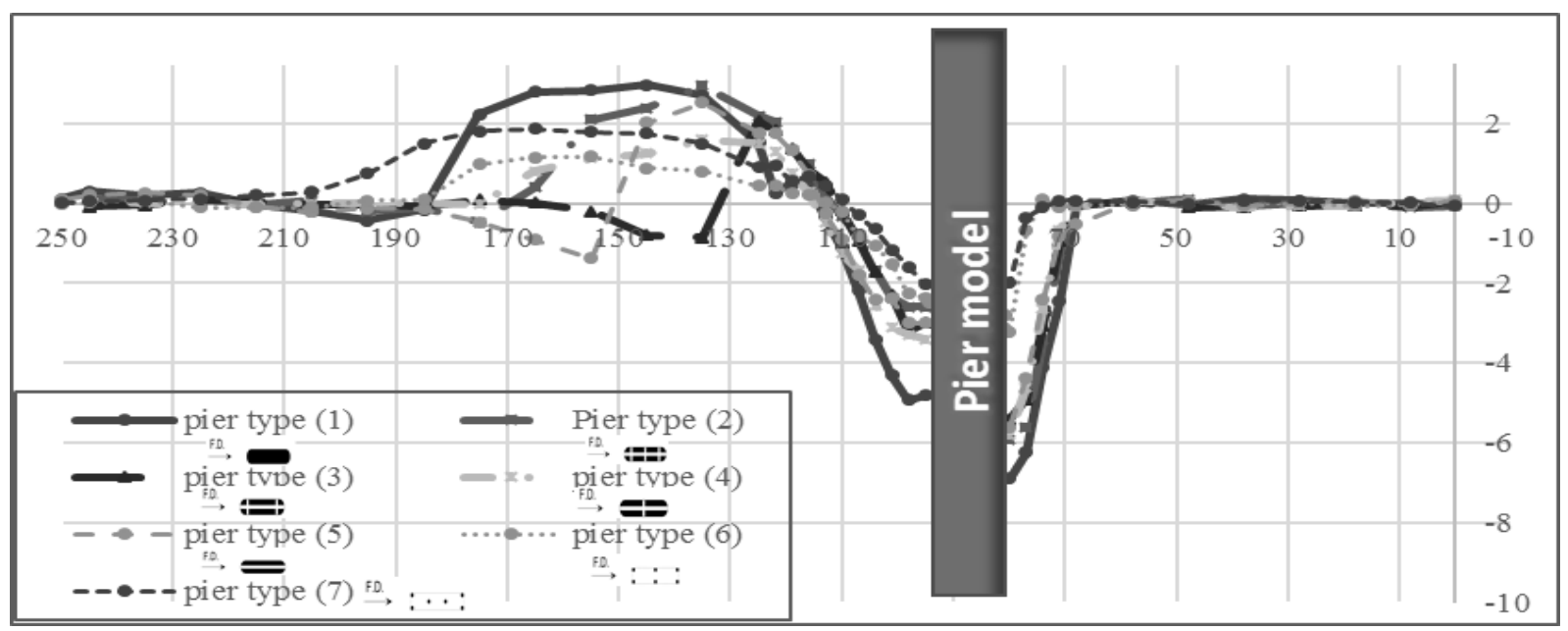

Fig.7. Longitudinal scour hole profile for studied pier types at $Q=18$ lit $/ \mathrm{s}, \mathrm{y}=20.0 \mathrm{~cm}$ and $\mathrm{F}_{\mathrm{r}}=0.21$. 
Figures (8 to 10) display the drawings of $\left(\mathrm{d}_{\mathrm{s}} / \mathrm{y}\right),\left(\mathrm{w}_{\mathrm{s}} / \mathrm{b}\right)$ and $\left(\mathrm{l}_{\mathrm{s}} / \mathrm{b}\right)$ against $\left(\mathrm{F}_{\mathrm{r}}\right)$ for all tested pier types. Generally, the figures show the relative scour hole depth, width, and length increase with the increase of $\left(F_{r}\right)$. Moreover, the results show the maximum scour hole dimensions are significantly affected by the existence of slots. Where, the ratios of maximum decrease in relative scour hole depths regarding to that at pier type (1a) are $88 \%, 92 \%, 88 \%, 88 \%, 85 \%, 93 \%$ for pier types (2), (3), (4), (5), (6) and (7) respectively. Also, the maximum reduction values in the relative scour hole widths are $46 \%, 53 \%, 40 \%$, $53 \%, 70 \%, 73 \%$ for pier type (2), (3), (4), (5), (6) and (7) respectively. Furthermore, the relative scour hole lengths reduced are $40 \%$, $69 \%, 68 \%, 47 \%, 78 \%, 79 \%$ for pier type (2), (3), (4), (5), (6) and (7) respectively. This reduction may be due to the reducing of the turbulence of horseshoe vortex of the flowing water around the piers.

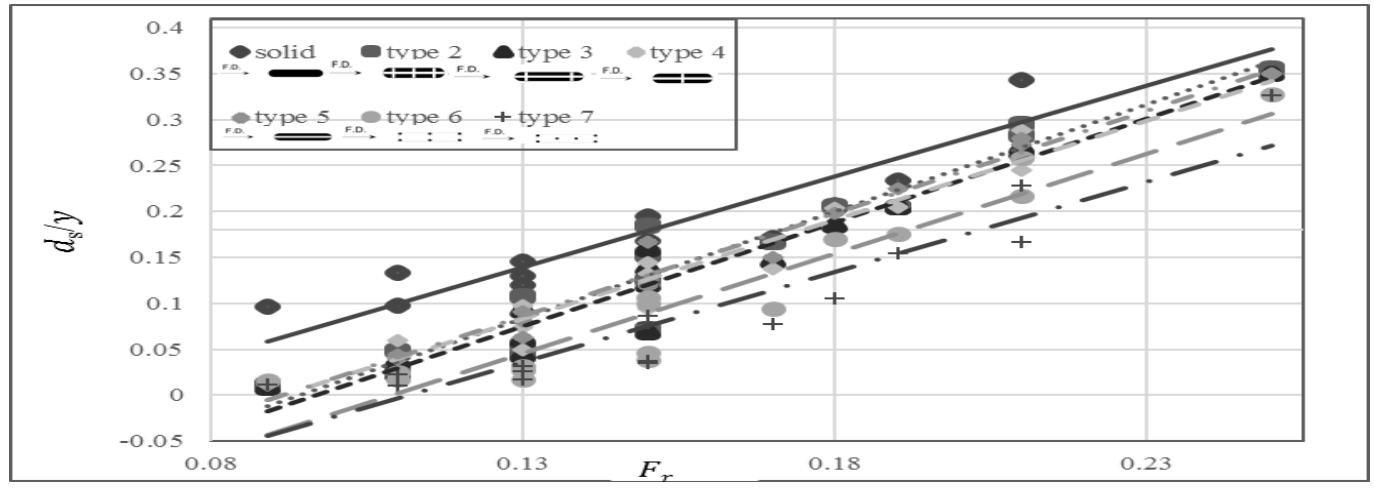

Fig.8.Values of relative scour hole depth $\left(d_{s} / y\right)$ versus Froud number $\left(F_{r}\right)$ for different pier types.

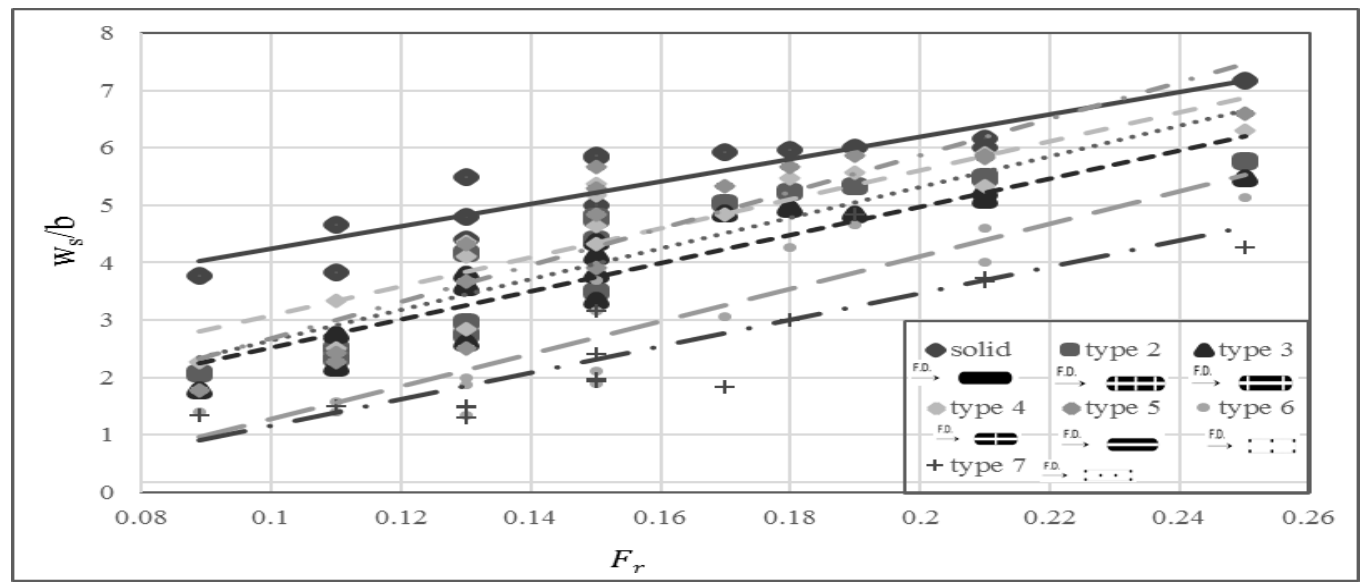

Fig.9.Values of relative scour hole width $\left(\mathrm{w}_{\mathrm{s}} / \mathrm{b}\right)$ versus Froud number $\left(\mathrm{F}_{\mathrm{r}}\right)$ for different pier types. 


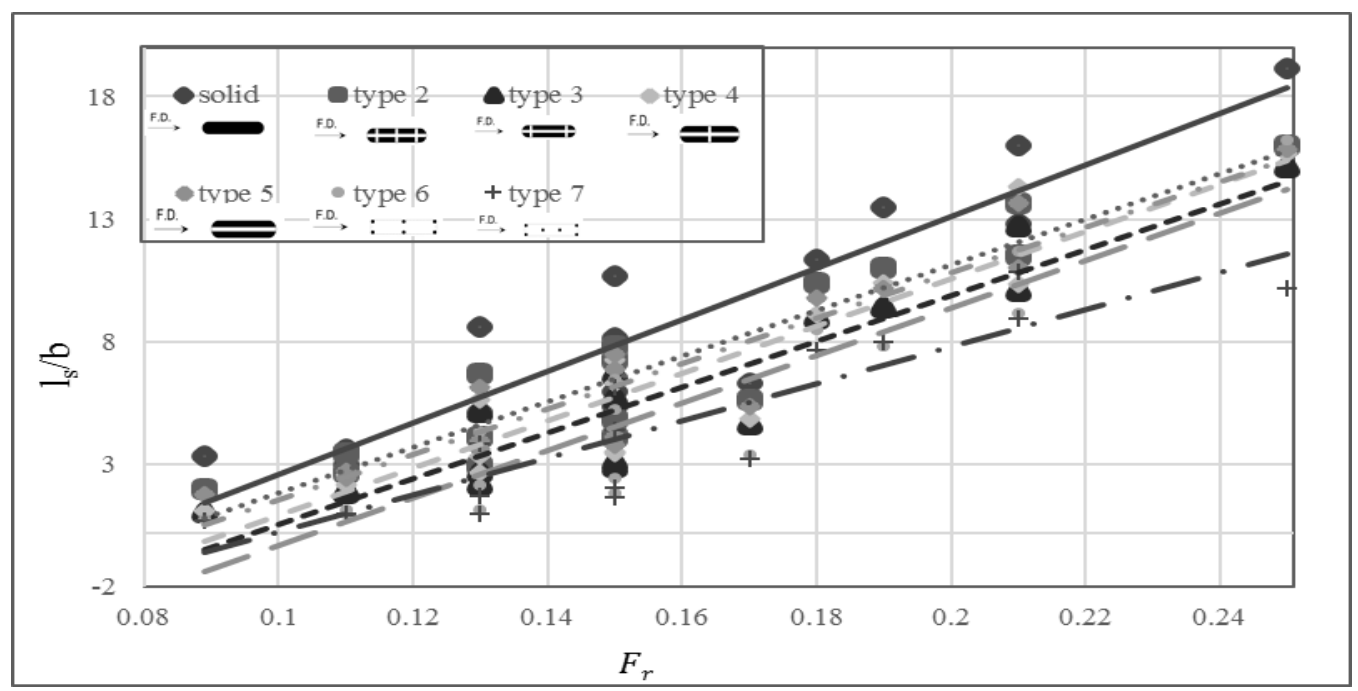

Fig.10. Values of relative scour hole length $\left(l_{s} / b\right)$ versus Froud number $\left(F_{r}\right)$ for different pier types.

Figures (11 to 13) represent the relations between $\left(\mathrm{d}_{\mathrm{s}} / \mathrm{y}\right),\left(\mathrm{w}_{\mathrm{s}} / \mathrm{b}\right)$ and $\left(\mathrm{l}_{\mathrm{s}} / \mathrm{b}\right)$ with $\left(\mathrm{u} / \mathrm{u}_{\mathrm{c}}\right)$ for all tested pier types. The figures show that, the variations of relative scour dimensions are directly proportional with $\left(\mathrm{u} / \mathrm{u}_{\mathrm{c}}\right)$. This may be due to the increase of flow velocity, which resulted from the decrease of water way area which increases the shear velocity corresponding of threshold of sediment motion, and a vertical pressure gradient is increased along the stagnation plane on the pier. This gradient produces a down flow in front of the pier, which is the main cause of erosions at bridge piers. It acts like a vertical jet in eroding the bed material.

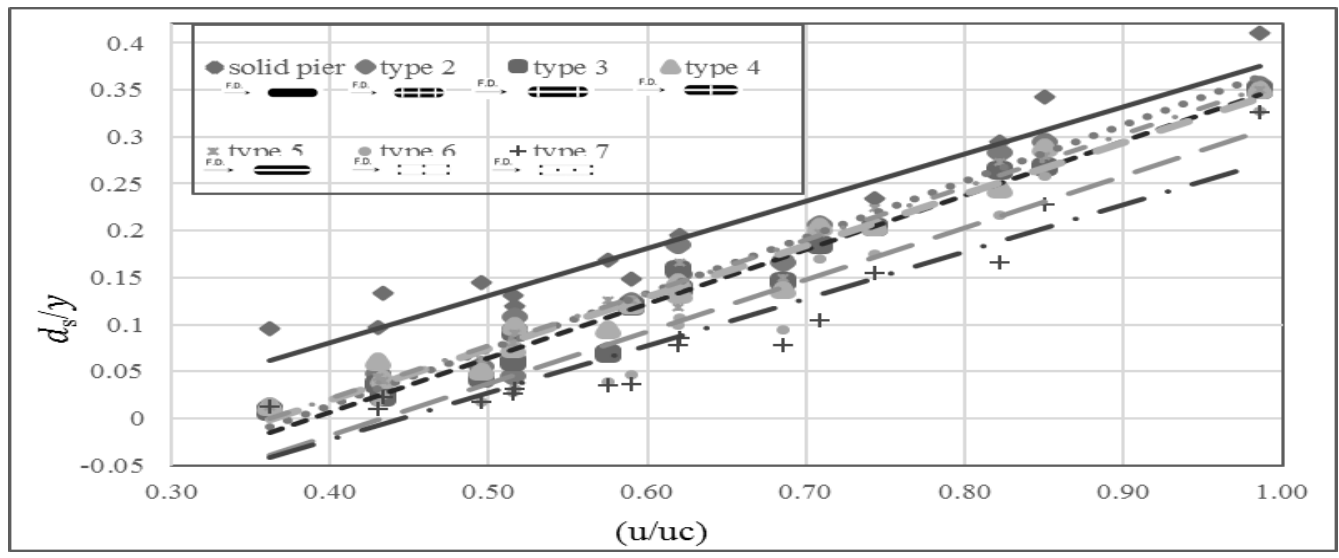

Fig.11. Values of relative scour hole depth $\left(d_{s} / y\right)$ versus $\left(u / u_{c}\right)$ for different pier types. 


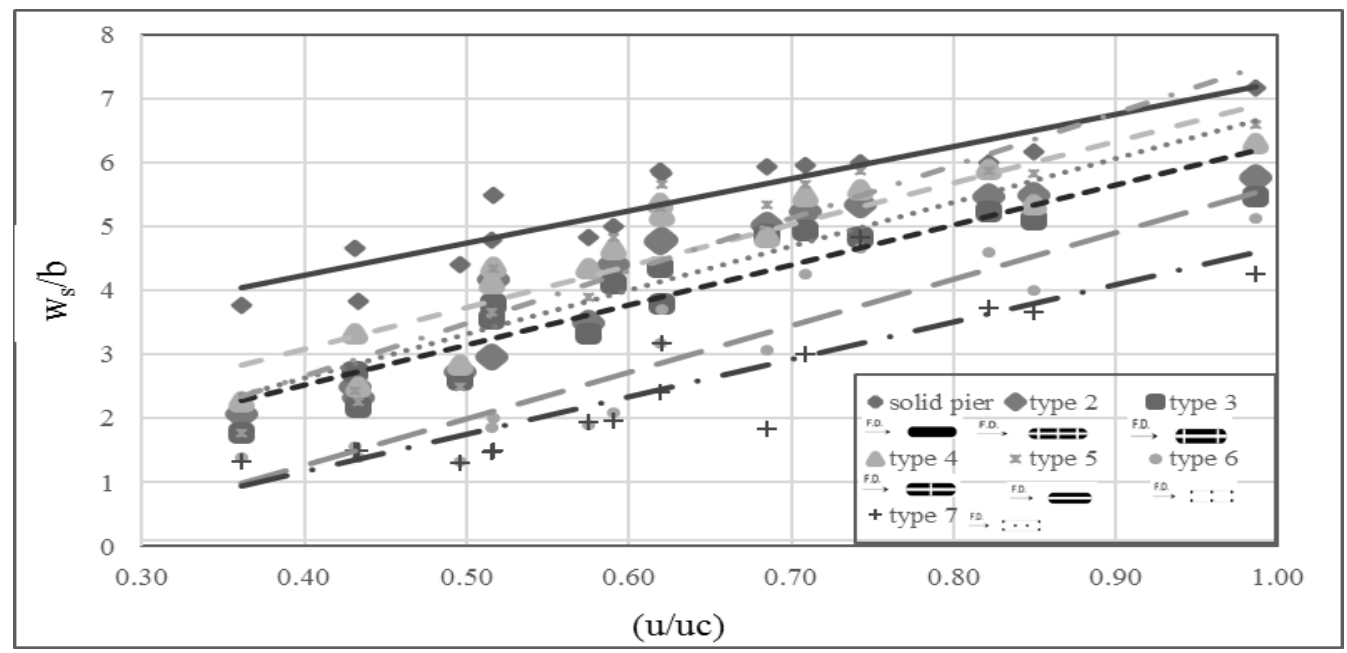

Fig.12. Values of relative scour hole width $\left(\mathrm{w}_{\mathrm{s}} / \mathrm{b}\right)$ versus $\left(\mathrm{u} / \mathrm{u}_{\mathrm{c}}\right)$ for different pier types.

Figures (14 to 16) show the relationship between $\left(\mathrm{d}_{\mathrm{s}} / \mathrm{y}\right),\left(\mathrm{w}_{\mathrm{s}} / \mathrm{b}\right)$ and $\left(1_{\mathrm{s}} / \mathrm{b}\right)$ with $\left(\mathrm{Q} / \mathrm{b}^{2} \mathrm{u}\right)$, for the all examined pier types. The figures demonstrate that the relative scour hole dimensions increase with the increase of $\left(\mathrm{Q} / \mathrm{b}^{2} \mathrm{u}\right)$. This may be due to the damping of the turbulence of horseshoe vortex. Also, at constant value of $\left(\mathrm{Q} / \mathrm{b}^{2} \mathrm{u}\right)$, the relative scour hole dimensions increase by increasing the flow discharge.

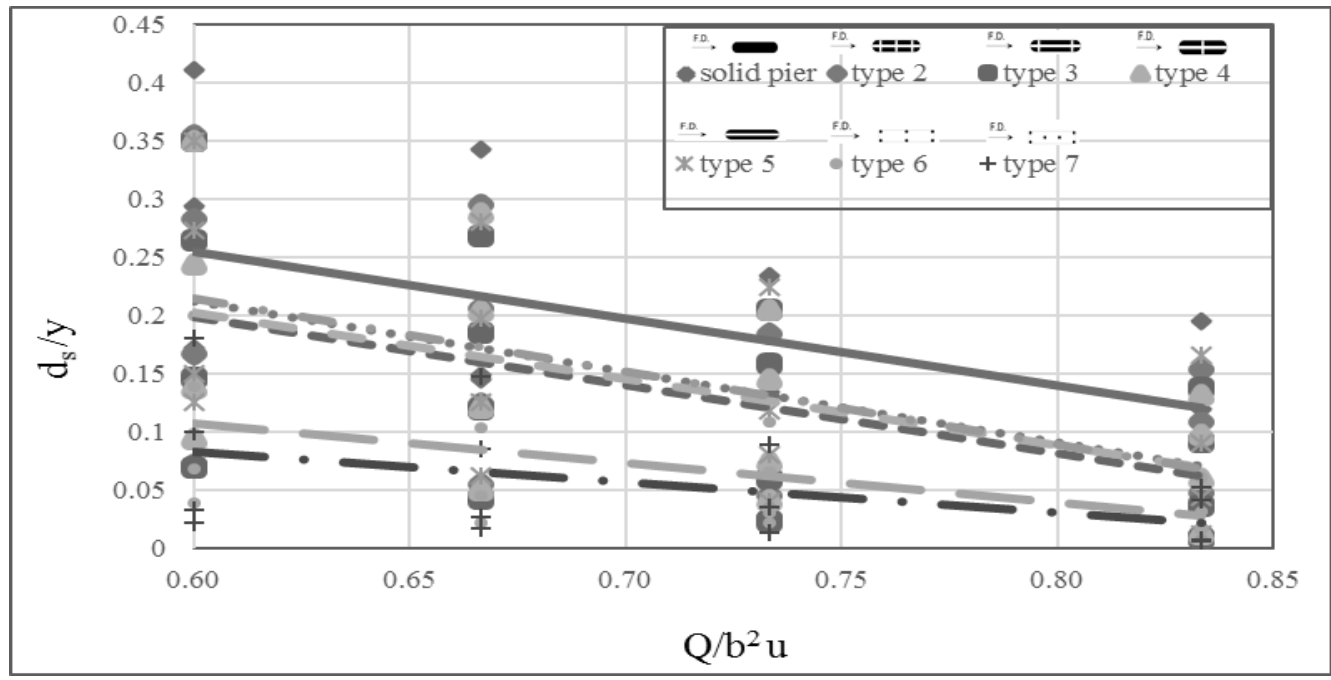

Fig.13.Values of relative scour hole length $\left(1_{s} / b\right)$ versus $\left(u / u_{c}\right)$ for different pier types. 


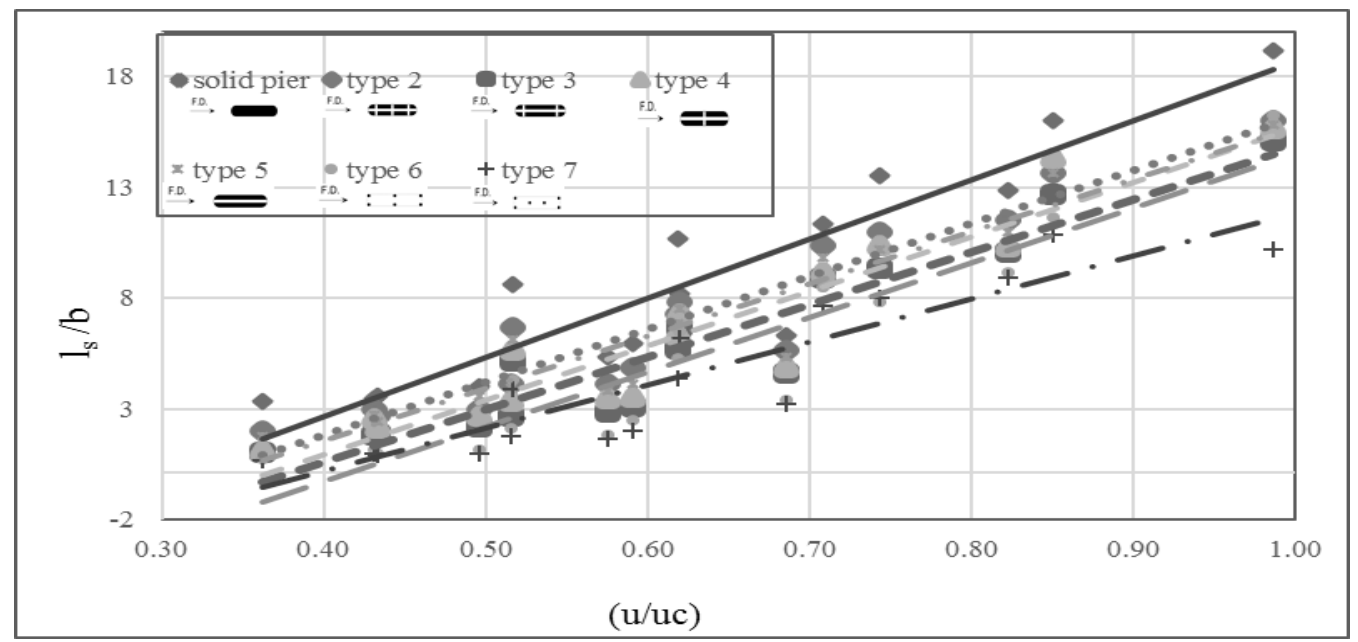

Fig.14.V alues of relative scour depth $\left(\mathrm{d}_{\mathrm{s}} / \mathrm{y}\right)$ versus $\left(\mathrm{Q} / \mathrm{b}^{2} \mathrm{u}\right)$ for different pier types.

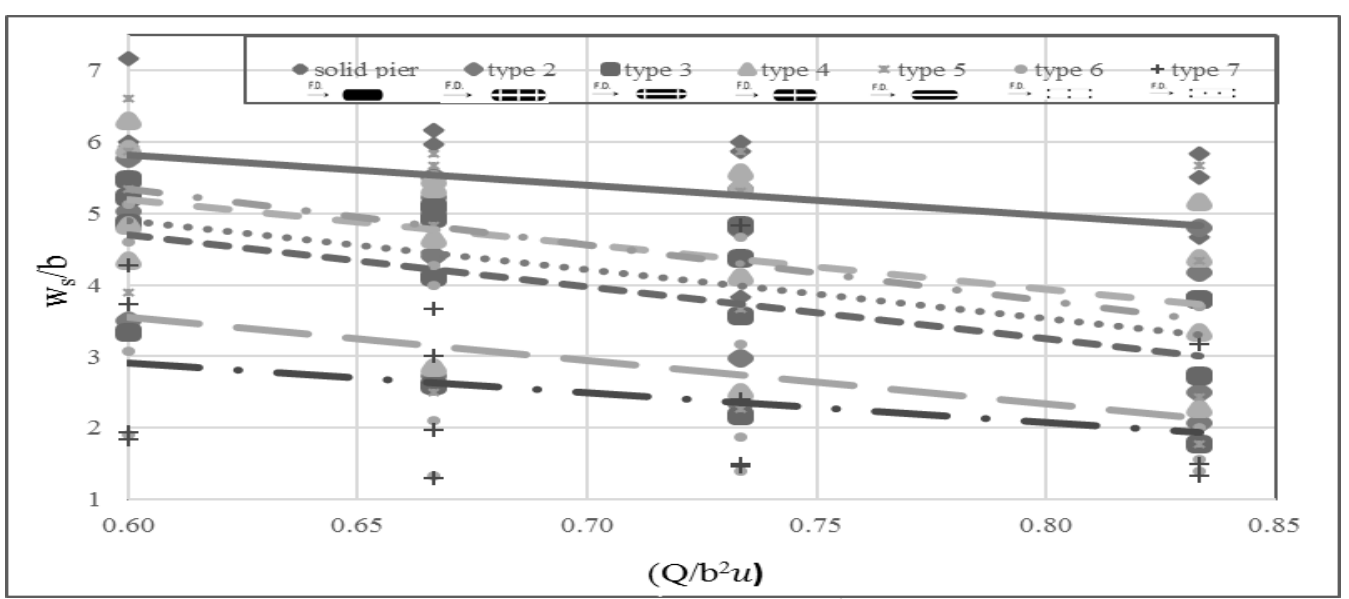

Fig.15.Values of relative scour hole width $\left(\mathrm{w}_{\mathrm{s}} / \mathrm{b}\right)$ versus $\left(\mathrm{Q} / \mathrm{b}^{2} \mathrm{u}\right)$ for different pier types.

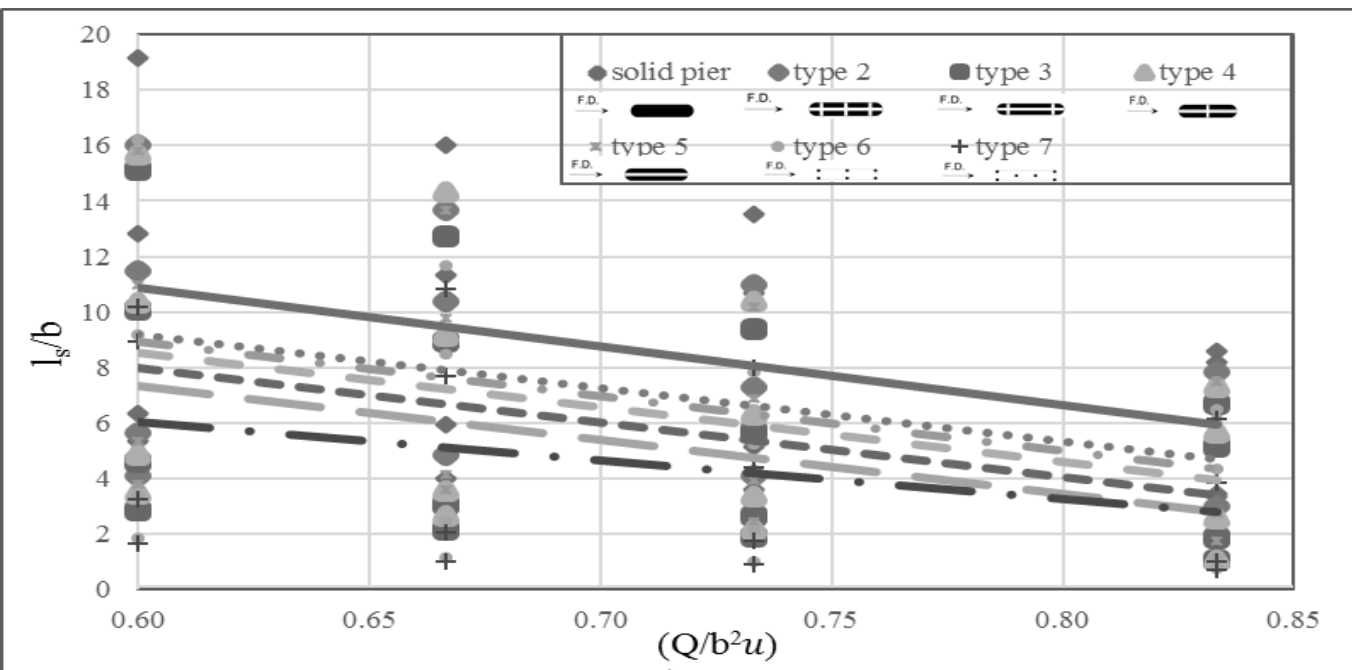

Fig.16.Values of relative scour length $\left(\mathrm{l}_{s} / \mathrm{b}\right)$ versus $\left(\mathrm{Q} / \mathrm{b}^{2} \mathrm{u}\right)$ for different pier types. 
In order to investigate which pier type has the most significant effect on the elimination of scour dimensions, volume of scouring materials due to the examined pier types were compared using a bar graph as shown in (Fig. 17). It is seen from the figure the increase of scour hole volume with the decreasing of flow depth and with the increasing of flow discharge. From this figure, the reduction in maximum scour hole volume ranged from
(3.2\% to $84.5 \%),(18.6 \%$ to $85 \%),(22.4 \%$ to $80.7 \%),(12.8 \%$ to $72.6 \%),(22.6 \%$ to $81.7 \%)$, (55.5\% to $89.4 \%$ ) for pier types (2), (3), (4), (5), (6) and (7) respectively. It is clear from previous discussions that the minimum scour hole dimensions occurred at pier type (7) in comparison with the tested pier types. Moreover, they are minimum with pier type (3) in comparison with the oblong piers only.

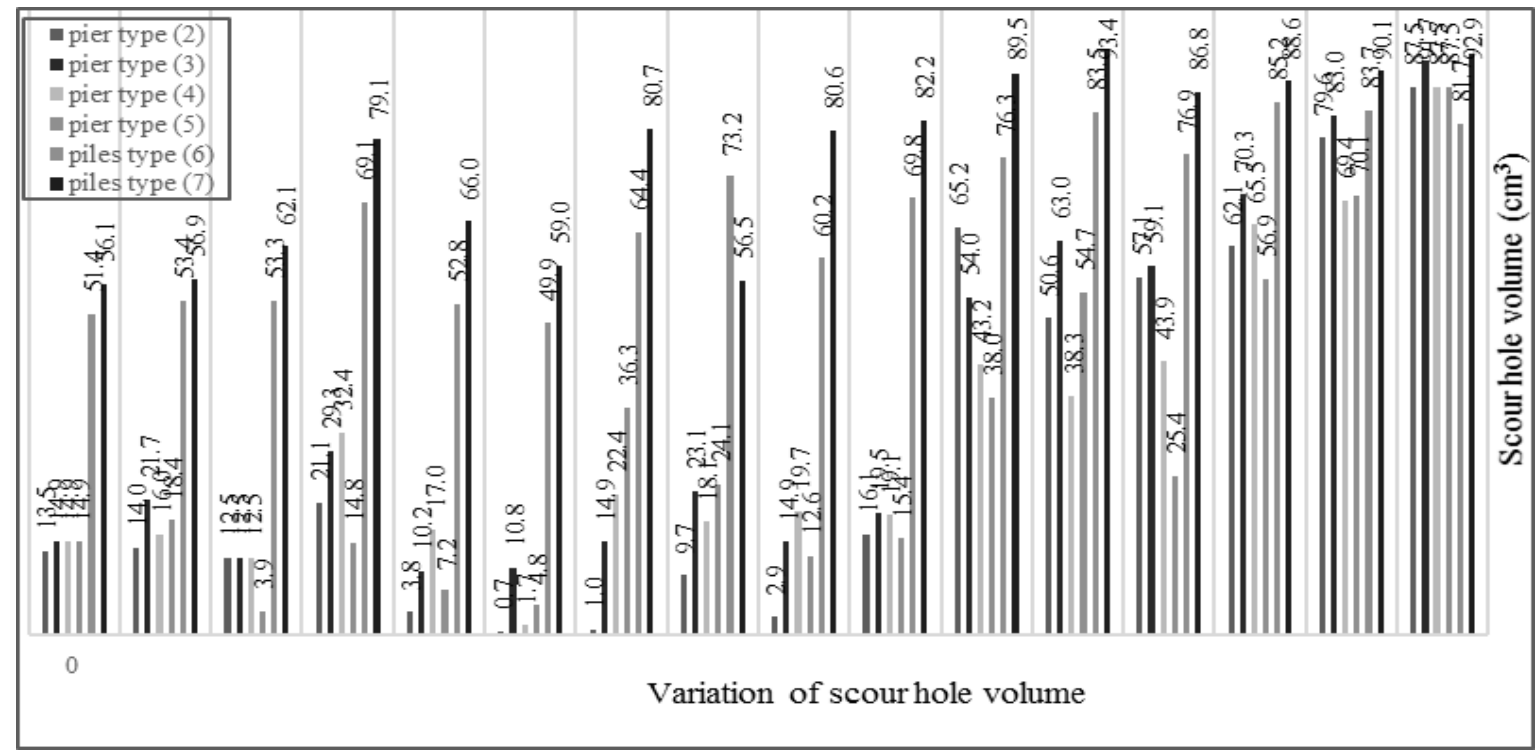

Fig.17.Values of scour hole volume $\left(\mathrm{cm}^{3}\right)$ for different pier types at different discharges and upstream water levels.

\section{Prediction of Scour Dimensions by Using Multiple Linear Regression Analysis (M.L.R):}

In this section multiple linear regression analysis is used to develop empirical formulas describing the relative scour hole dimensions $\left(\mathrm{d}_{\mathrm{s}} / \mathrm{y}\right),\left(\mathrm{w}_{\mathrm{s}} / \mathrm{b}\right)$ and $\left(\mathrm{l}_{\mathrm{s}} / \mathrm{b}\right)$ as a function of $\left(\mathrm{F}_{\mathrm{r}}\right.$, $\mathrm{u} / \mathrm{u}_{\mathrm{c}}$, and $\left.\mathrm{Q} / \mathrm{b}^{2} \mathrm{u}\right)$. Figures 18,19 and 20 show the correlation between the regression model and the experimental data values for pier types (2), (3), (4), (5), (6) and (7). As shown from the figures that the developed empirical formulas are represented the experimental results of $\left(\mathrm{d}_{\mathrm{s}} / \mathrm{y}\right),\left(\mathrm{w}_{\mathrm{s}} / \mathrm{b}\right)$ and $\left(\mathrm{l}_{\mathrm{s}} / \mathrm{b}\right)$ in a good agreement with correlation coefficient $\left(\mathrm{R}^{2}\right)=$ $89 \%, 94 \%$, and $93 \%$, respectively.

$$
\begin{aligned}
& \frac{d_{s}}{y}=-3.094 F_{r}+1.173 \frac{u}{u_{c}}-0.18 \frac{Q}{b^{2} u} \\
& \frac{w_{s}}{b}=-54.44 F_{r}+20.184 \frac{u}{u_{c}}-0.38 \frac{Q}{b^{2} u} \\
& \frac{l_{s}}{y}=-204.349 F_{r}+70.068 \frac{u}{u_{c}}-7.716 \frac{Q}{b^{2} u}(10)
\end{aligned}
$$

These empirical formulas (8 to 10) are valid for the ranges of experimental results of this study as follow: $0.089 \leq \mathrm{F}_{\mathrm{r}} \leq 0.25,0.36 \leq \mathrm{u} / \mathrm{u}_{\mathrm{c}}$ $\leq 0.99$ and $0.6 \leq \mathrm{Q} / \mathrm{b}^{2} \mathrm{u} \leq 0.83$. 
Fig.18. Correlation between the regression model (Eq. 8) and the experimental data values for relative scour hole depth $\left(d_{s} / y\right)$ for tested pier types.
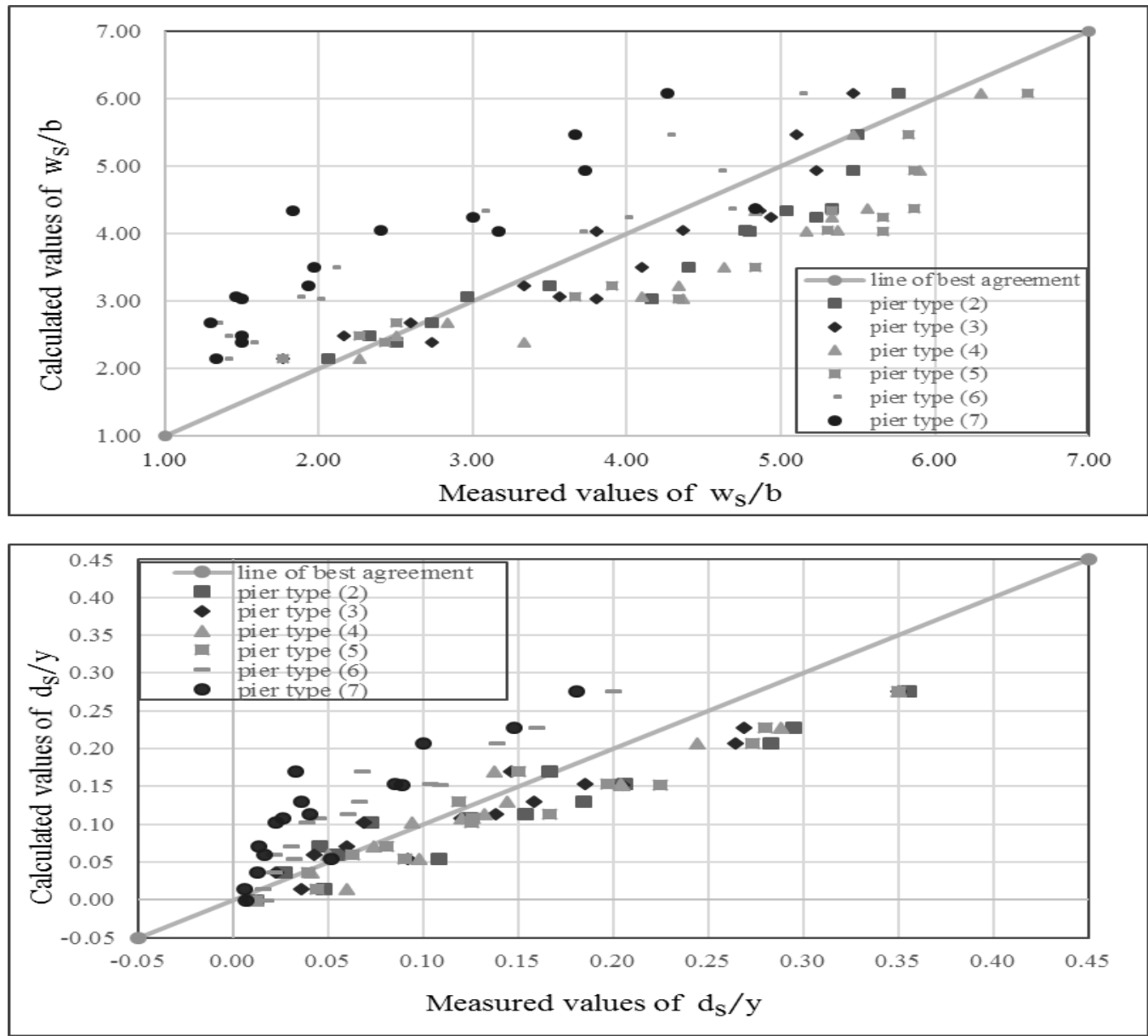

Fig.19. Correlation between the regression model (Eq. 9) and the experimental data values for relative scour hole width $\left(w_{s} / b\right)$ for all pier types. 


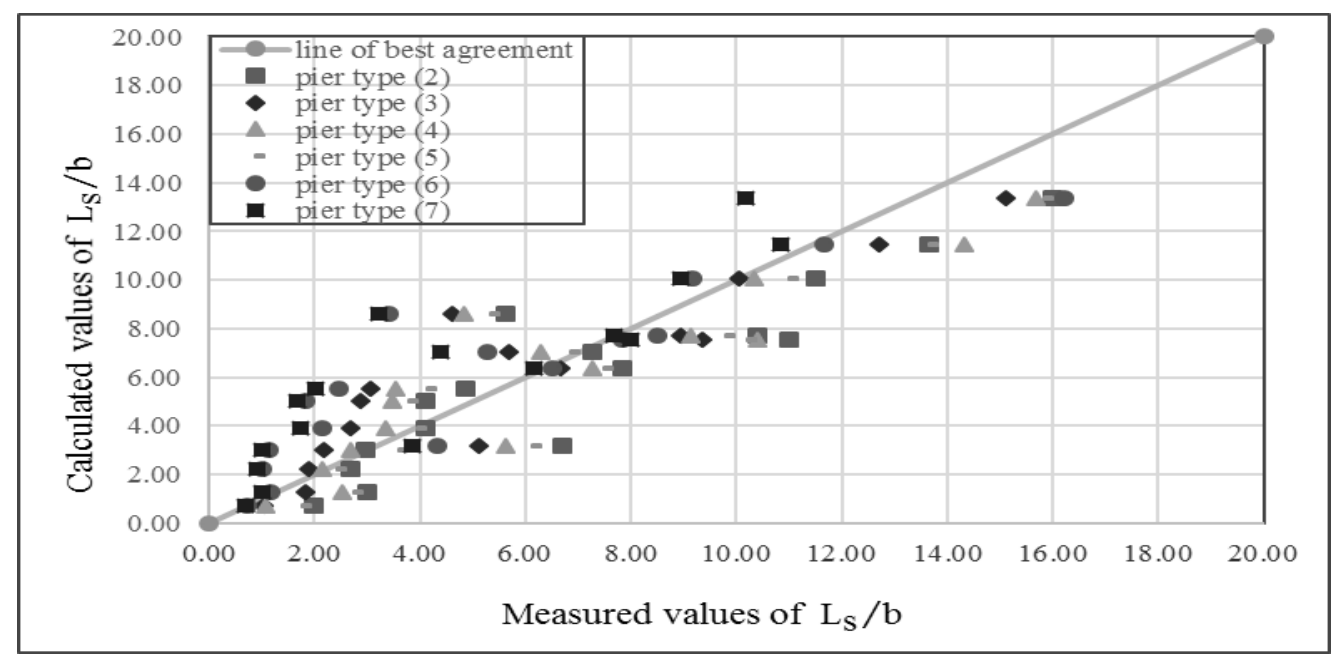

Fig. 20.Correlation between the regression model (Eq. 10) and the experimental data values for relative

\section{CONCLUSIONS}

Based on the analysis and discussions of the experimental data, the following conclusions may be drawn as follows:

1- Scour hole dimensions' increases by increasing the Froude number.

2- Maximum scour dimensions for pier groups are smaller than those for oblong piers.

3- Rectangular slots and pier groups were considered good tools for reducing the formation of scour hole and from economical point of view they are better.

4- The rectangular slot connecting with two openings along the pier sides (pier type 3) gives the best reduction of scour dimensions (depth, width and length) for the oblong piers, which are 92\%, 53\%, 69\% and 85\% respectively.

5- Pier group of staggered arrangement (pier type 7) gives the best scour reduction for the all tested models; 93\%, 73\%, 79\% and 89\%, respectively.

6- The multiple linear regression analysis is used for driving empirical formulas $(8,9$ and 10) for estimating the relative scour hole dimensions ds $/ y, w_{\mathrm{s}} / \mathrm{b}$, and $l_{\mathrm{s}} / \mathrm{b}$ respectively, for the different pier models.

\section{ACKNOWLEDGMENTS}

This article is extracted from a master dissertation entitled "Effect of some parameters on local scour around bridge piers".
The authors think it is necessary to appreciate all those people who helped them in the Hydraulics Laboratory of Civil Engineering Department, Assiut University.

\section{REFERENCES}

[1] Abozeid, G. "Scour at abutment of one-vent bridges.", J. of Eng. Scie., Assiut Univ., Vol. 32, pp. 1091-1105, July, (2004).

[2] Abozeid , G. A., Hassan I. M., Shima, M. A., "3-D numerical simulation of flow and clear water scour by interaction between bridge piers" Proc. of the Tenth Water Tech. (IWTC) Conf., Alex., March 2006.

[3] Ali, N. A., "A contribution to sediment transportation with reference to hydraulic resistance", M. Sc. Thesis, Civil Eng. Dept. Assiut Univ., 1978.

[4] Breusers, H. N. C., and A. J. Raudkivi. "Scouring. IAHR hydraulic structures design manual 2.", A. A. Balkema, Rotterdam, The Netherlands, (1991).

[5] Chang, F., and Davis, S. "Maryland SHA Procedure for Estimating Scour at Bridge Abutments Part 2-Clear Water Scour.", Stream Stability and Scour at Highway Bridges: Compendium of Stream Stability and Scour Papers Presented at Conferences Sponsored by the Water Resources Engineering (Hydraulics) 
Division of the American Society of Civil Engineers, ASCE., (1998).

[6] Chatterjee, S. S., and Ghosh, S. N., "Submerged horizontal jet over erodible bed ", J. of Hyd. Div., ASCE, 106(HY), Nov. 1980.

[7] Chiew, Y. M. "Scour protection at bridge piers.", J. of Hyd. Eng., Vol. 118, No. 9, pp. 12601269, Sept., (1992).

[8] Choi, S. U., and Choi, B. "Prediction of timedependent local scour around bridge piers.", Water and Environment Journal, Vol. 30., No. 1, pp. 1421, (2016).

[9] Christensen, Z. M. "Reduction of local scour around bridge piers: Combined system of aerofoil and slot.", the Faculty of Eng., Southern Queensland Univ., pp. 1-150, October, (2009).

[10] El-Razek, M., El-Motaleb, M. A., and Bayoumy, M. "Scour reduction around bridge piers using internal openings through the pier.", Alexandria Engineering Journal, Vol. 42., No. 2, pp. 241-248, (2003).

[11] Grimaldi, C., Gaudio, R., Calomino, F., and Cardoso, A. H. "Countermeasures against local scouring at bridge piers: slot and combined system of slot and bed sill.", J. of Hyd. Eng., Vol. 135., No. 5, pp. 425-431, (2009).

[12] Heidarnejad, M., M. Shafai Bajestan, and A. Masjedi. "The effect of slots on scouring around piers in different positions of 180-degrees bends.", World Applied Sciences Journal, Vol. 8., No. 7, pp. 892-899, (2010).

[13] Khodabakhshi, A., Mojtaba, S., and Abdolnabi A.K. "Experimental study on effect of slot level on local scour around bridge pier.", Int. J. of Res. in Eng. and Tech., Vol. 3., No. 2, pp. 103108, (2014).

[14] Kumar, V., Raju, K. G. R., and Vittal, N. "Reduction of local scour around bridge piers using slots and collars.", J. of Hyd. Eng., Vol. 125., No. 12, pp. 1302-1305, (1999).

[15] Melville, B. W. "Local scour at bridge site", School of Eng., Univ. of Auckland, New Zeland, pp. 1-277, 1975.

[16] Melville, B. W., and Yee-Meng Chiew. "Time scale for local scour at bridge piers.",
Journal of Hydraulic Engineering, Vol. 125., No. 1, pp. 59-65, (1999).

[17] Melville, B. W., and Coleman, S. E. "Bridge scour. ", Water Resources Publication, (2000).

[18] Moncada-M, A. T., Aguirre-Pe, J., Bolivar, J. C., \& Flores, E. J. "Scour protection of circular bridge piers with collars and slots." J. of Hyd. Res., Vol. 47., No. 1, pp. 119-126, (2009).

[19] Neill, C. R. "Guide to bridge hydraulics, Roads and Transportation Association of Canada. ", University of Toronto Press, Toronto, (1973).

[20] Setia, B., and Bhatia, K. "Sour protection by a slot through a model bridge pier." J Indian Water Res. Soc., Vol. 33., No. 1, pp. 9-15, (2013).

[21] Siddiqui, N. A. and Elsebaie, I. H. "Experimental investigation of grain size effect on the temporal variation of local scour around bridge piers. ", J. of Water Res. and Pollution Studies, Vol. 2., No. 3, (2017).

[22] Tseng, M. H., Yen, C. L., and Song, C. C. "Computation of three-dimensional flow around square and circular piers.", Int. J. for numerical methods in fluids, Vol. 34., No. 3, pp. 207-227, (2000).

[23] Vittal, N., Kothyari, U. C., and Haghighat, M. "Clear-water scour around bridge pier group." J.of Hyd. Eng., Vol. 120., No. 11, pp. 1309-1318, (1994).

[24] Zarrati, Amir R., H. Gholami, and M. B. Mashahir. "Application of collar to control scouring around rectangular bridge piers.", J. of Hyd. Res., Vol. 42., No. 1, pp. 97-103, (2004). 
"دراسة تقليل النحر الموضعي حول دعامات الكباري المستطيلة باستخدام القتحات "

الملخص العربى:

تعتبر الكباري أحد المنشآت الهيدروليكية التي تقام خلال المجاري المائية والتي عادة ما ترتكز على دعامات خلال المجري المائي. ويعتبر النحر حول هذه الدعامات أحد الأسباب الرئيسية التي تؤدي إلى انهيارها. لذا يلجأ المصممون إلى العديد من وسائل الحماية للحد من خطورة هذه الظاهرة. ويوجد الكثير من الدراسات النظرية والمعملية لدراسة بعض العوامل المؤثرة في هذه الظاهرة. ولكن لوحظ أن عدد قليل من هذه الدراسات التي تهتم بدراسة ظاهرة النحر حول الدعامات المستطيلة. ولذلك كان الغرض من هذه الدراسة هو إيجاد طريقة جديدة لتقليل النحر الذي يحدث حول دعامات الكباري المسنطيلة عن طريق عمل فتحات في جسم الدعامة، والتي تعتبر من طرق الحماية الاقتصادية وتقليل جهود الصيانة وتكاليفها بشكل كبير وكذللك تحسين الأداء الهيدروليكي لسريان الماء. وذلك عن طريق عمل فتحات مسنطيلة بأنشال مختلفة في مستوي أفقي واحد. الفتحة الأولى في مقدمة الدعامة والتي تتصل بفتحات على جانبي ومؤخرة الدعامة بنفس شكل الفتحة المستطيلة. وعن طريق فرق الضغوط الموجود حول الدعامة يمكن دفع التيار من المقدة إلى الجوانب وبهذه الطريقة يسمح بالسريان من خلال الدعامات ويمكن تقليل الدوامات المتكونة أمام الدعامة وبالتالي تقليل النحر الذي يحدث حول الدعامة. وبإستبدال النماذج المستطبلة بمجموعتين من الدعامات الدائرية بترتيبين مختلفين على أن يكون محيط مجموع الدعامات الدائرية يعادل محيط الدعامة الصلبة المستطيلة. أجريت الدراسة بمعمل الهيدروليكا بقسم الهندسة المدنية، كلية الهندسة جامعة أسيوط على نموذج معملي مكون من قناة مكثوفة بطول 20 منز وعرض 0.3 منر وعمق 0.5 منز وقد بلغ عدد التجارب التي تم اجرائها 112 تجربة، حيث تم اجراء 16 تجربة لكل نموذج من عدد سبعة نماذج بأثكال مختلفة (حيث تم تغير معدل التصرف أربع مرات وفي كل مرة نم تغير عمق المياه أربع مرات) لبتراوح رقم فرويد بين 0.089 إلى 0.25 للتصرفات المستخدمة. وفي جميع التجارب تم دراسة تأثثر شكل الفتحة على ابعاد حفرة النحر • تم عمل قياس كامل لأبعاد حفرة النحر والقطاع الطولي لمناسيب قاع المجرى المائي. بتحليل ودراسة كل من النتائج المعملية، أمكن استخلاص النتائج التالية: 1) استخدام أسلوب الفتحات في جسم الدعامة يخفض قيمة كل من العمق الأقصى للنحر وعرض وطول وحجم حفرة النحر وكانت أكبر قيمة لهذا التخفيض عند النموذج رقم (7) (استبدال الدعامة المستطيلة بمجموعه من الدعامات الدائرية) حيث بلغت قيمة النقص في أقصى أبعاد حفرة النحر (عمق وعرض وطول الحفرة) 93\% \% 73\% و79 \% على التوالي. من النتائج السابقة يتضح أن الفتحات خلال جسم دعامات الكباري ذات تأثثر فعال في الحد من ظاهرة النحر • بالإضافة إلى أن استبدال الدعامات المصمتة بمجموعة من 
Vol. 39, No. 1. January 2020

الدعامات الدائرية اثتتت كفاءة عالية في التقليل من ابعاد حفرة النحر، وكذلك اقتصادية في استهلاك مواد البناء. ثم استتناج معادلات تجريبية غير بعدية (بإستخدام التحليل الرياضي) يمكن بواسطتها التعرف على أبعاد حفرة النحر لجيع النماذج

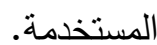

